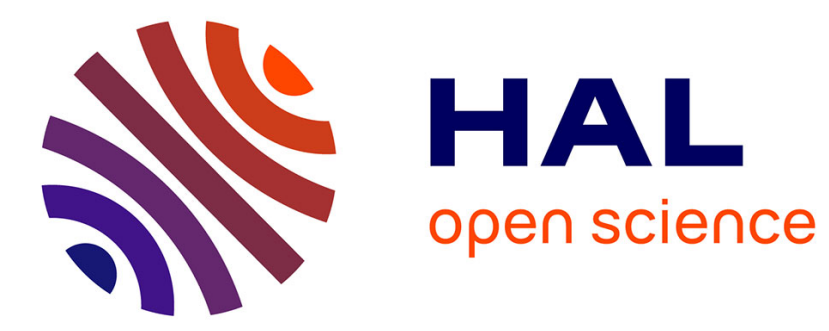

\title{
Multivariability of Rights in the Structure of Corporate Legal Relations
}

Anatoliy Kostruba, Dmytro Lukianov

\section{To cite this version:}

Anatoliy Kostruba, Dmytro Lukianov. Multivariability of Rights in the Structure of Corporate Legal Relations. Journal of Advanced Research in Law and Economics, 2019, 10 (7), pp.2035-2029. 10.14505/jarle.v10.7(45).13 . hal-02867743

\section{HAL Id: hal-02867743 \\ https://hal.science/hal-02867743}

Submitted on 15 Jun 2020

HAL is a multi-disciplinary open access archive for the deposit and dissemination of scientific research documents, whether they are published or not. The documents may come from teaching and research institutions in France or abroad, or from public or private research centers.
L'archive ouverte pluridisciplinaire HAL, est destinée au dépôt et à la diffusion de documents scientifiques de niveau recherche, publiés ou non, émanant des établissements d'enseignement et de recherche français ou étrangers, des laboratoires publics ou privés. 


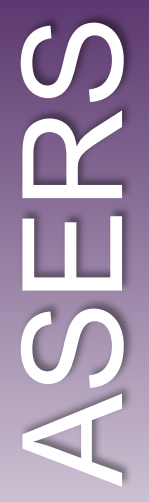

\section{Ournal of Advanced Research

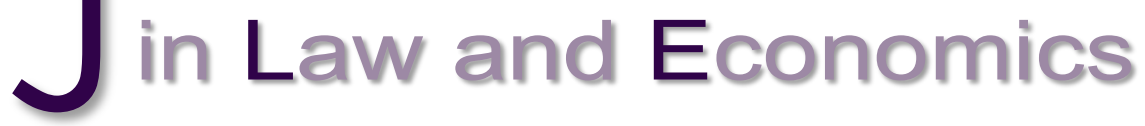

\section{Quarterly}

volume X

Issue 7(45)

Winter 2019

ISSN: 2068-696X

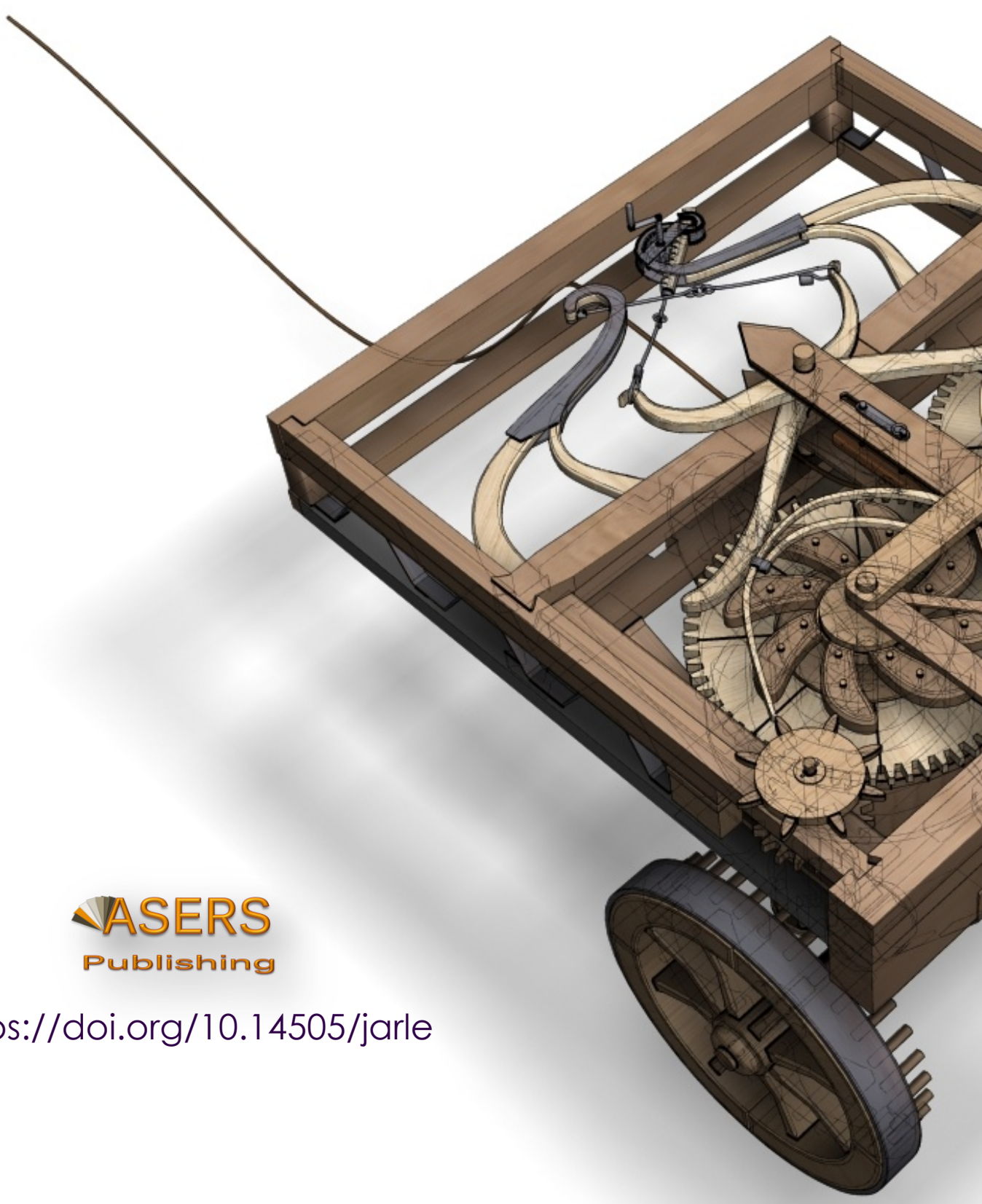

Journal's DOI: https://doi.org/10.14505/jarle 


\section{Winter 2019}

Volume X, Issue 7(45)

\section{Editor in Chief}

Mădălina Constantinescu

Spiru Haret University, Romania

\section{Assistant Editor}

Popîrlan Cristina

University of Craiova, Romania

Rajmund Mirdala

Technical University of Kosice,

Slovakia

\section{Editorial Advisory Board}

Huseyin Arasli

Eastern Mediterranean University,

North Cyprus

Mihai Bădescu

Bucharest University of Economic

Studies, Romania

Jean-Paul Gaertner

Ecole de Management de

Strasbourg, France

Shankar Gargh

Editor in Chief of Advanced in

Management, India

Anthony J. Greco

University of Louisiana-Lafayette, USA

Arvi Kuura

Pärnu College, University of Tartu, Estonia

\section{Piotr Misztal}

Technical University of Radom,

Economic Department, Poland

Adrian Cristian Moise

Spiru Haret University, Romania

\section{Peter Sturm}

Université de Grenoble 1 Joseph

Fourier, France

\section{Rajesh K. Pillania}

Management Development Institute, India

\section{Russell Pittman}

International Technical Assistance Economic Analysis Group Antitrust Division, USA

Rachel Price-Kreitz

Ecole de Management de

Strasbourg, France

Laura Ungureanu

Spiru Haret University Romania

Hans-Jürgen Weißbach, University of Applied Sciences - Frankfurt am Main, Germany

\section{Contents:}

Legal Contracts and Legal Customs in the History of the Law of the Kazakh Society

by Ermek B. Abdrasulov, and Murat G. Gubaidullin

... 1951

Legal Culture of Public Servants:

The Comparative Legal Analysis of the Formation Practices of Various Countries

by M.A. Alimbekova, A.S. Ibrayeva, G.T. Ichshanova, K.R. Useinova,

and N.S. Ibrayev

Administrative Procedure: European Standards and Conclusions for Ukraine

by Iryna V. Boiko, Oleksandr T. Zyma, Yuliia V. Mekh, Olha M. Soloviova,

and Valentyna A. Somina

\section{Judicial Nature of Evidence in Criminal Proceeding}

by Valery P. Gmyrko, Mykola Ye. Shumylo, Viacheslav V. Vapniarchuk,

Oksana V. Kaplina, and Vasily P. Shybiko

Tendencies of Reforming Legislative Regulation in the Field of Evidence in Civil Procedure of Ukraine

by Oksana O. Hrabovska, Olena S. Zakharova, and Oleksandra O. Karmaza ... 1984

The Legal Regime of the Mediation Contract

by Claudiu Ignat

Regulation of Combining Brokerage Activities in the Securities Market in the Legislation of the EAEU Countries

by Renat K. Kanatov

International Legal Regulation of the Children's Rights

by Kairat Kapsalyamov, Saule Kapsalyamova, Dinara Osmanova,

Baurzhan Zhuzbaev, and Bakhyt Zhusipova

The Place and History of the Activities of Kazakhstan

in the United Nations Organization (1991 - 2016)

by Gani M. Karasayev, Zhandos N. Zhaxygeldinov, Kanat A. Yensenov,

Bekmurat R. Naimanbayev, and Zhanat S. Bakirova 


\section{Winter 2019}

Volume $\mathrm{X}$, Issue $7(45)$

Historical-Research Overview of Socio-Economic and Politico-Legal Basis

for the International Relations of Kazakhstan on the Post-Soviet Space (1991 - 1995)

by Gani M. Karasayev, Seytkali Zh. Duisen, Bekmurat R. Naimanbayev,

Bolat S. Zhumagulov, and Talgatbek M. Aminov

Subjects of Tax Relations: Features of Legal Status and Classification

by Liubov M. Kasianenko, Natalia I. Atamanchuk, Olena O. Boiko-Slobozhan,

Olena V. Shakirova, and Sergiy O. Danilov

\section{Legal Nature of Contract for Provision of State Medical Services}

by Hanna V. Kolisnykova, Oksana V. Lekhkar, and Yana O. Samsonova

Multivariability of Rights in the Structure of Corporate Legal Relations

by Anatoliy V. Kostruba, and Dmytro Lukianov

Amicus Curiae Institute in the Constitutional Process

by Anzhelika Krusian, Iryna Zhytotovska, Volodymyr Mikhalov,

Kseniia Kuli-Ivanchenko, and Mariana Afanasieva

General Theoretical Aspects of Legal Development

by Anatolii Kryzhanovskyi, Denys Manko, Olena Sierykh, Natalia Atamanova, and Antonina Zghama

Temporal Boundaries of an Arbitration Agreement as a Prerequisite for Submitting a Dispute to International Commercial Arbitration

by Nataliia S. Kuznietsova, Yurii D. Prytyka, and Mykhailo M. Khomenko

Scientific and Legal Aspect for Conducting of Operational Measures to Counter Threats of Terrorist Acts upon Their Commission as a Challenge to the Social Community

by Viktor V. Nalutsyshyn, Vasyl M. Yurchyshyn, and Vasyl V. Cherepushchak 2060

\section{A Modern Vision of Methodological Approaches in Regulation of Labor Relations}

by Oleksii I. Ostapenko, Leonid O. Ostapenko, Oleksandra L. Khytra, Maryana Tsvok, and Solomia Vasyliv 


\section{Winter 2019}

Volume $\mathrm{X}$, Issue $7(45)$

General Theoretical Analysis of the Mechanism of Legal Tax Regulation

by Kateryna O. Plotnikova, levgeniia A. Ananieva, Dmytro M.Osypov,

Victoriia O. Zakrynytska, and Natalia O. Maksymenko

Factors in the Fight Against Corruption

in the Context of Civil Society and the Rule of Law

by Tetiana S. Podorozhna, Vitalii A. Vdovichen, and Liudmyla V. Vakariuk

Theoretical and Legal and Economic Characteristics of Novellization of Taxation in Ukraine

by Halyna V. Rossikhina, Vasyl V. Rossikhin, Tetyana O. Barabash,

Viktoriia M. Shcherba, and Olha O. Sydorenko

Actual Vectors of Research in the Doctrine of the Judiciary

by Valentyna M. Skrypniuk, Maryna S. Bulkat, and Serhii A. Drobotov

\section{Legal Support of Industrial Accident Prevention}

by Viktoria Strelnyk, Tetiana Churilova, Natalia Hres, and Tetiana Myronenko

\section{ASERS Publishing}

Copyright ${ }^{\odot} 2019$, by ASERS ${ }^{\circledR}$ Publishing.

All rights reserved.

No part of this publication may be reproduced, stored in a retrieval system or transmitted in any form or by any means, electronic, mechanical, photocopying, recording, scanning or otherwise, except under the terms of the Romanian Copyright, Designs and Patents Law, without the permission in writing of the Publisher.

Requests to the Publisher should be addressed to the Permissions Department of ASERS Publishing:

apg@aserspublishing.eu

\section{http://journals.aserspublishing.eu} ISSN 2068-696X

Journal DOI: https://doi.org/10.14505/jarle Journal's Issue DOI:

https://doi.org/10.14505/jarle.v10.7(45).00
ECtHR Practice of Resolving Disputes on Royalty Taxation for the Use of Copyright Objects

by Daria Sukhanova, Siuzannatsurkanu, Ruslan Ennan, Olha Balatska, and Lesia Strelbitska

Countering Fraud Committed Using Information Technology in Kazakhstan

by Lyazzat A. Temirzhanova, Nurtai K. Imangaliev, Bakhytzhan Zh. Sagymbekov, Almaz A. Eshnazarov, and Almaz Zh. Syzdykov

Geostrategic Features of Interaction Between Kazakhstan and Iran in the Regional and World Aspect: Analysis and Evaluation

by Akmaral U. Tyulyubayeva, Madina M. Abisheva, Aikerim A. Turuntayeva, and Saltanat T. Jakubayeva

Legal Implication of Ownership in Common in Roman Private Law and Its Reception by European Jurisdictions

by Timur T. Uteubayev, and Antonina S. Kizdarbekova 


\section{Winter 2019}

Volume X, Issue $7(45)$

\section{ASERS Publishing}

Copyright ${ }^{\odot} 2019$, by ASERS ${ }^{\circledR}$ Publishing.

\section{All rights reserved.}

No part of this publication may be reproduced, stored in a retrieval system or transmitted in any form or by any means, electronic, mechanical, photocopying, recording, scanning or otherwise, except under the terms of the Romanian Copyright, Designs and Patents Law, without the permission in writing of the Publisher.

Requests to the Publisher should be addressed to the Permissions Department of ASERS Publishing:

apg@aserspublishing.eu
Conceptual Approaches to Understanding the Essence of Proof in the Science of Criminal Process in Ukraine

by Viacheslav V. Vapniarchuk, Oksana V. Kaplina, Mykola Ye. Shumylo, and Anush R. Tumanyanc

Content, Correlation, and Meaning of Categories 'Legal Person' and 'Legal Personality': General - Purpose Aspects

by Vitalii V. Volynets, Volodymyr A. Sichevliuk, and Ilona V. Kaminska

Legal Regulation of Perishable Foodstuffs Transportation

by Anna Yanovytska, and Halyna Yanovytska

Evolution of the Forms of Threats to the Inviolability of Property Rights during Interstate Military Conflicts

by Vitaliy Yarotskiy, and Denys Spiesivtsev

Avoidance the Norms of Legislation as Manifestation of the Deviant Behavior of Participants of Civil Relations

by Yurii M. Yurkevych, Ivan V. Krasnytskyi, and Khrystyna V. Maikut

Legal Aspects of Biomedical Experiments on Humans in Russia

by Sergey I. Zakhartsev and Viktor P. Salnikov

Service Functions of Tax Regulation for the Purposes of State Development in the Globalized Environment

by Zivar Z. Zeynalova

Actual Issues of Treaty Law in CIS Countries

by Olga I. Zozulyak, Oksana S. Oliinyk, Liliana V. Sishchuk,

Nataliia A. Slipenchuk, and Yuliia I. Paruta

Justice as a Fundamental Principle of Law: A Meta-Normative Context

by Yevgen Ye. Zvonkov 


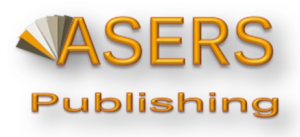

DOI: https://doi.org/10.14505/jarle.v10.7(45).13

\title{
Multivariability of Rights in the Structure of Corporate Legal Relations
}

\author{
Anatoliy V. KOSTRUBA \\ Department of Civil Law, \\ Vasyl Stefanyk Precarpathian National University, Ivano-Frankivsk, Ukraine \\ anatolii.kostruba@pnu.edu.ua \\ Dmytro LUKIANOV \\ Department of Private International Law and Comparative Law, \\ Yaroslav Mudryi National Law University, Kharkiv, Ukraine \\ lukianov1975@gmail.com
}

\section{Suggested Citation:}

Kostruba, A.V., and Lukianov, D. 2019. Multivariability of Rights in the Structure of Corporate Legal Relations, Journal of Advanced Research in Law and Economics, Volume X, Winter, 7(45): 2035 - 2039. DOI: 10.14505/jarle.v10.7(45).13. Available from: http://journals.aserspublishing.eu/jarle/index.

\section{Article's History:}

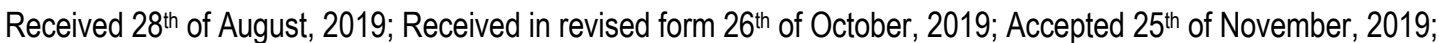

Published 31 st of December, 2019.

Copyright ${ }^{\odot} 2019$, by ASERS ${ }^{\circledR}$ Publishing. All rights reserved.

\begin{abstract}
:
The article is devoted to the study of the structure of corporate legal relations, establishing the mechanism of their formation. Legal relations as a form of social relations are in constant development due to the activity of social ties in society. As a result, new types of social interaction emerge and develop that require an appropriate legal form of ordering. Such ordering is selfregulated by the participants of the respective relations in the process of accumulation of property, non-property components, organizational and so on. The study found that the formation of corporate legal relations is the result of a combination of property, non-property and organizational components. The organizational component of corporate relations is to streamline the activities of individuals in the process of combining their efforts at the stage of emergence of such relationships, as well as to streamline this activity of participants in corporate relationships in the process of their implementation. It can be concluded that the proprietary nature of corporate legal relationships is conditioned by the material interest of the participants in such relationships to receive appropriate satisfaction from their participation in them. The corporation is managed through a nonproperty segment.
\end{abstract}

Keywords: corporate legal relations; civil legal relations; organizational relations; property relations; non-property relations.

JEL Classification: K10; K11; K15.

\section{Introduction}

The problem of corporate relations formation in the civil law of Ukraine has a rather wide scientific debate among representatives of the civil law community as well as representatives of other branches of legal science. At the present stage of the development of the legal doctrine, corporate relations are considered from the standpoint of substantive, binding, and corporate-legal approaches, each of which contains the priority of the same elements in the structure of legal relations. In addition, some scholars are exploring corporate relationships in the context of the parity of those rights that are part of them. Much attention has been paid to the study of this question, but the following problematic questions have been left unanswered.

Legal relations are one of the fundamental categories of the theory of law. It is they who are the means of inertia in the structure of legal matter. With their help, law comes to fruition: rights are exercised, legal obligations are fulfilled. Therefore, the study of the elements of corporate legal relations, their uniqueness or variability, method and sequence of accumulation is relevant for the science of civil law in Ukraine. The purpose of the scientific 
publication is to investigate the nature of subjective civil rights and legal responsibilities in their polarity, which influences the formation of corporate legal relations in the civil law of Ukraine.

Despite the lack of a generally recognized concept of the term legal relations, their classification has been formed quite sufficiently today. Thus, the division of legal relations into property and non-property is quite established. Also, in the theory of law, legal relations are systemized into absolute and relative, real and obligatory. By the way, the latter concerns the specific classification of property relations. The above structure has practical implications. Thus, depending on the type of legal relationship, the object of social relations that correlate with the legal has a corresponding mode of existence. Given the above, each type of social connection has a different meaningful scope of legal relations.

\section{Formation of Higher Order Civil Relations in the Property Sphere}

The basis of property relations consists of two groups of relations: the relationship of ownership of property to a person (real) and trade turnover (obligatory). The latter, in turn, differ depending on the chosen method of protection, as well as the order of implementation. Non-property legal relationships, because of their personal nature, are non-transitional. Along with the said, non-proprietary rights are inseparable from the holder of these rights, so there is certain specificity of the grounds for their origin and termination. However, it is necessary to separate this group of legal relations, which by their nature are oriented to the ordering (normalisation) of other social relations, the actions of their participants or the formation of social entities. These are the so-called organizational relations, a place in the subject of civil law which is defined by Krasavchikov (2017): 'Civil organizational relations are relationships based on the equality of their participants, which express, within the law, the activities of citizens and organizations in ordering their relations, coordinating efforts in the process of implementation of state or own initiative'. It is reasonable to note that in the civil law doctrine, different terms are used to reveal the concept under study: 'procedural relations' (Zakharov 2002); 'Procedures' (Davydova 2004). And according to Yu.P. Egorov (2004), such social relations are better called 'coordination', as they are established between not subordinated to each other parties.

However, the term 'organizational', in authors' view, semantically most clearly reflects the character and nature of the phenomenon under study. Notwithstanding the debate nature of this issue in the context of the classification of organizational relations to the subject of civil law, the scientific credibility of the scientist's position is beyond doubt. The nature of the legal connection of the subjects of social interaction is not limited solely to the property or non-property component. The existence of social relations is conditioned by the activities of a person who is aimed at achieving a particular result of property or non-property content. Such activity undoubtedly has a legal form of its existence, and for the appropriate purpose, it is also filled with legal content. Thus, the above activity of a person receives all the features of legal relations, which due to the private legal nature of the subject matter of the organization concerned become civil.

The position wrongness of O.A. Krasavchikov (2017), in authors' opinion, is limited only to a way of systemizing organizational legal relations in one line with property and non-property. The scientist reveals the relationship between them. Unfortunately, it is limited, leaving in mind that such a relationship is indeed systemically necessary, but it is based on different criteria for classification of organizational, property (non-property) relationships. To assert that organizational relations, along with property and non-property, are an independent element of the subject of civil law regulation is incorrect. Thus, the criterion for classification of legal relations on property and non-property is their object. At the same time, the criterion for classification of legal relations into organizational and other (non-organizational) is their content. In view of the above, it is wrong to detach or contrast the organizational element from the property. They are at different levels of the same system. But, this is the theoretical side of the question.

At the same time, analyzing the debatable issue of classification of legal relations, it should be concluded that in the 'pure' form property and non-property relations, absolute or relative do not exist. Even the relations of things alienation that are of a material nature contain a non-material component, such as the right to information. In turn, non-property relationships cannot be implemented outside property. When hiring, a guarantee of protection of non-property relations are corresponding compensatory ways of their implementation, among them compensation for damage that is property. Thus, the specific nature of legal relations gives the aggregate amount of powers that make up their content. It is the overwhelming number of them in the structure of legal relations that gives them property or not property type, real or obligatory, or even organizational.

If to focus on the individual elements of the relationship (object, content), the latter are structured into the main and derivatives. The main ones are such that have a targeted orientation (organizational, regulatory, security), the purpose of their existence. Derivatives are a format for ensuring the implementation of the main (property, non- 
property). In this case, the self-organization of civil legal relations takes place at two levels. From the beginning, at the level of determining the goals of the relationship, then at the level of establishing the nature of the achievement of such goals. The above makes it possible to conclude that the classification of civil legal relations is determined by the sum of the mono-level order components constituting its powers. Empirically, this allows to explain the principle of the formation of so-called 'equal rights'. This phenomenon was at one time brought to the attention of Spasibo-Fateeva (2010), noting that: 'There are pairs of civil rights in civil law. It is not advisable to consider them individually, since they are exclusively inextricably linked with one another and have the legal effect of satisfying all the interests and needs of their carriers and giving regulation the level that is capable of doing so. Therefore, in the study of such rights ... personal non-property and property rights should be regarded as paired'. The rationality of the scientist's idea is beyond doubt. The variant combination of different types of competences, instilling their types within the framework of civil relations is natural in relation to the subject of civil legal regulation of social relations. By the way, public-law relations that have an imperatively focused shade are devoid of such a property. In authors' opinion, only the restriction of the combination of rights to one pair (property - non-property), as well as the obvious interdependence, can be a remark to her position. This is clearly not enough to explain the nature of such rights.

First, the combination of powers is not limited to a couple of non-property-property. Property, divided into material and obligations, may also be involved in the accumulation of a critical mass of competencies, which in the future will lead to the emergence of a particular type of civil relationship. An example is an easement relationship that combines binding and property rights. Secondly, accumulation of powers in civil legal relations is not exhausted with the couple combination. Their consolidation in the structure of legal relations can be ensured by almost three powers, which in addition to property and non-property are also organizational. And when necessary, it also has the power to protect, converting regulatory civil relationships into protective ones. In essence, such an idea provides additional argument in a dispute about the structure of subjective civil law and the inclusion in its constituent right to defend or separate it into an independent subjective civil right in favor of the latter.

This combination results in complex, higher-order civil (legal) relationships round a particular entity. Thus, as a result of the combination of property and non-property relations, the object of which are family benefits, family relationships are formed. Another example is the intellectual property relationship as a result of the parity of property and non-property rights round the results of creative activity. It is seen that the family legal relations and legal relations of intellectual property are characterized by the 'couple character' of the rights about the peculiarity of existence of which I.V. Spasibo-Fateeva (2010) stated.

\section{Dualism in the Organizational Component of Corporate Legal Relations}

Adding to the couple character of property and non-property competencies of the organizational element will lead to the formation of relationships, the object of which is not only the good, which is characteristic of family and intellectual property relations, but also activities to organize the conditions for the existence of such benefits. These are corporate legal relationships as a form of individually substantive social relations in which self-regulated organizational, property and non-property subjective rights and legal obligations of their participants in relation to the corporation underlie. The corporation is the object of such legal relationships. A corporation itself is of value in the totality of its features and is therefore subject to civil law. This allows to consider it from the material side, as an object of desire of participants of legal relations.

On the other hand, a corporation is an artificial entity. For its 'vitality', the ability to bear the result of its creation, it is filled with legal personality, which implies the existence of an organizational component that allows the corporation to function as a subject. Such an organizational component is 'in the shadow' of the entity corporation, ensuring its legal capacity in civil law. Hence, the intangible (non-property) side of relations between persons who are behind the 'veil' of the corporation. From the above the organizational nature of the relationship also discloses. Thus, it is the corporation that determines the formation of legal relations around and within it, which, given the above, form a specific type of legal relations in the civil law of Ukraine - corporate relations.

The organizational component of corporate relations is to streamline the activities of individuals in the process of combining their efforts at the stage of emergence of such relationships, as well as to streamline this activity of participants in corporate relationships in the process of their implementation. They are based on a structurally organizing component. Creating a legal entity involves organizing the actions of its members (founders). Functioning of a legal entity requires its structural organization. The existence of a legal entity in the civil turnover requires organizational coordination of its legal personality. In other words, the fact of the activity of a legal entity, from the moment of creation until the moment of its termination, implies organizational influence on the structure of corporate legal relations by their participants. Its absence (of an organizational component) precludes the genesis of property and non-property competences in the structure of corporate legal relationships among their participants. 
By the way, a legal entity cannot be created in the absence of an organizational component. It should be noted that, on the example of corporate legal relations, the specific classification of organizational and legal relations developed by 0.O. Krasavchikov (2017) is most clearly reflected.

The scientist considers most significant such classification in content, on the basis of which the organizational and legal relations are divided into:

(a) organizational-prerequisite (forming). With regard to the subject matter of this study, their content is to implement the provisions of Article 4, Part 2 of Article 26, 35-36, 50, 52, 67, 75-76 of the Law of Ukraine 'On Business Associations' (1991), etc. (joint stock company, limited company and additional company responsibility is created and acts on the basis of the charter, a full and limited partnership - on the founding agreement).The legal norms that form the organizational-prerequisite corporate legal relations are enshrined in Article 9 of the Law of Ukraine 'On Joint Stock Companies' (2008). For example, in order to create a joint-stock company, founders must hold a private (private) placement of its shares, constituent assembly fees and carry out state registration of the joint-stock company, etc.;

(b) organizational-delegating, which are characterized by conferring organizational-administrative powers to manage a legal entity in the process of implementing corporate legal relations. In particular, Articles 59, 62, 68, 81 'On Business Associations' (1991) stipulates the scope of power of a corporate body, Article 39 of the Law of Ukraine 'On Joint Stock Companies' (2008);

(c) organizational-control enable one person to control the actions of another, who is in a certain relationship. In particular, Article 63 of the Law regulates the procedure for exercising control over the activities of a directorate (director) of a legal entity through the institute of the audit committee. In a joint-stock company, the following functions are performed by a supervisory board of a joint-stock company;

(d) the criterion of organizational-implementing is absent in the classification of A.O. Krasavchikov (2017), however, is consistently appropriate in such a system. Therefore, the organizational component in the activity of a legal entity accompanies its functioning in the civil turnover at every stage of legal regulation of corporate relations. It is also present at the stage of law implementation, the content of which is the implementation of subjective corporate rights and legal corporate duties. These are relations related to the convening of the general meeting of the members (founders) of the corporation, the relations of participation in it, the decision making (voting), etc.

There is dualism in the property component of corporate relationships. It is based on a systematic combination of the substantive element and the obligation law. The proprietary nature of corporate legal relationships is conditioned by the material interest in the objective form of the desire of the parties to such relationships to obtain a corresponding materialized effective satisfaction from their participation in them. That is, their content is a value-price aspect. The real or value aspect of the property component of the corporate legal relationship is revealed through the realization of owner's powers. It is the right of a participant (founder) of a legal entity to own, use and dispose of its share in the authorized capital. That is, the ownership of a participant (founder) of a share that is a subject of ownership. Therefore, the real element of the property component of corporate legal relations is: in an ownership of a share of the established and formed size of an authorized capital of a legal entity; ownership of dividends in proportion to the share of the statutory capital of the legal entity; in the right of ownership of part of the property of the legal entity in proportion to the share of the established and formed size of the authorized capital of the legal entity, but in case of withdrawal of the participant (founder) from the legal entity.

The obligatory (value) aspect of the property component of the corporate legal relationship is derived from the real one and reflects the counter active actions of the participants of the corporate legal relations, which mediate the process of moving the corporate material results between them, which are: the size of an authorized capital of a legal entity; the right to claim to a legal entity for a part of the legal entity's property is proportional to the share of the legal entity's established and formed share capital in the event of a participant (founder) leaving the legal entity; the right of a claim to other participants (founder) on the exercise of the owner's real powers.

The non-property component of corporate relations semantically complements the two previous ones. Through the non-property segment, the identification of corporate relationships in the civil law system occurs. This is achieved through the activity of entities, the subject of which is not so much the movement of material goods, which is characteristic of property relations, but corporation management. Such management is carried out indirectly (formation of an executive body of a corporation, election of members of a supervisory board of a joint stock company) or directly (participation in general meetings, conducting affairs of a corporation, withdrawing from a legal entity, exercising control over activities of an executive body). It is definitely that the non-property component 
of corporate relations is personality-related, devoid of material content, has a purpose for meeting certain social needs, and ensures the exercise of freedom of social existence (the right to choose the occupation).

A characteristic feature of corporate relationships is that their organizational, property and non-property component are interconnected without prioritizing one of them over the other. In the absence of organizational formation of property, which is achieved by non-property in the corporate relationship is impossible. Absence of property component impedes the development of non-property (right to participate in management) and prevents the existence of organizational. The non-property component of the corporate legal relationship causes the positive development of the property component (the right to receive dividends from the results of the corporation's activity).

\section{Conclusions}

The studied allows to state the following. Legal relations as a form of social relations are in constant development. This development is due to the activity of social connections in society. As a result, new types of social interaction emerge and develop that require an appropriate legal form of ordering. This ordering is self-regulated by the participants of the respective relations as a result of the subjective accumulation of property, non-property components, organizational and so on.

In the process of such a configuration, a kind of public relations emerges, the basis of which is the interaction of individuals in the creation and existence of such artificial entity as a legal entity, the purpose of which is to satisfy a certain private interest. Such relations are dressed in the legal form of their reflection, which, taking into account the specifics of their object, as well as combinations of property, non-property and organizational components, a synthetic combination of real and obligatory in them is called corporate legal relations. Corporate legal relationships are an independent type of civil relationship, along with such as family legal relationships, residential legal relationships, intellectual property legal relationships. This conclusion is due to the civil legal nature of these relationships, the nature of the object of their legal regulation. The formation of corporate legal relations is the result of a combination of property, non-property and organizational components. At the same time such combination has eclectic character that does not allow to establish priority of any of the above elements in the structure of corporate legal relations.

\section{References}

[1] Davydova, G.N. 2004. Legal procedures in civil law. Institute of Economics, Management and Law.

[2] Egorov, Yu.P. 2004. The legal regime of transactions as a means of individual regulation. Nauka.

[3] Krasavchikov, O.A. 2017. Civic organizational relations. In: Categories of Civil Law Science: Selected Works, 45-56. Statut.

[4] Law of Ukraine 'On Business Associations' No. 1576-XII. 1991. https://zakon.rada.gov.ua/laws/show/1576-12.

[5] Law of Ukraine 'On Joint Stock Companies' No. 514-VI. 2008. https://zakon.rada.gov.ua/laws/show/514-17.

[6] Spasibo-Fateeva, I.V. 2010. Equal rights or another attempt to deal with personal non-pecuniary rights, to compare them with property rights and to disclose the importance of the category of 'even rights' and their types. In: R.A. Stefanchuk (Ed.), Personal Non-Property Rights: Problems of Theory and Practice of Application: Collection of Articles and Other Materials (pp. 139-165). Yurinkom Inter.

[7] Zakharov, V.A. 2002. Creation of legal entities: legal issues. NORMA. 
